E. B. Marliss $\cdot$ S. Chevalier $\cdot$ R. Gougeon •

J. A. Morais - M. Lamarche • O. A. J. Adegoke · G. Wu

\title{
Elevations of plasma methylarginines in obesity and ageing are related to insulin sensitivity and rates of protein turnover
}

Received: 3 June 2005 / Accepted: 30 August 2005 / Published online: 21 December 2005

(C) Springer-Verlag 2005

\begin{abstract}
Aims/hypothesis: Increased circulating methylarginines (MA) have been linked to the metabolic syndrome to explain endothelial dysfunction and cardiovascular disease risk. Proteins that contain MA are regulatory and release them during catabolism. We hypothesised that increased protein turnover in insulin-resistant states contributes to an increase in circulating MA. Materials and methods: We performed hyperinsulinaemic, euglycaemic, and isoaminoacidaemic experiments on 49 lean, obese and elderly subjects, with measurements of the kinetics of glucose and protein metabolism. Plasma MA, i.e. asymmetrical dimethylarginine (ADMA), symmetrical dimethylarginine (SDMA), and $N^{\mathrm{G}}$-monomethyl-L-arginine (NMMA), lipids and body composition were measured. Results: Insulin resistance of glucose and protein metabolism occurred in obese and elderly subjects. ADMA concentrations were 29 to $120 \%$ higher in obese and $34 \%$ higher in elderly than in lean subjects. SDMA were 34 and $20 \%$ higher in obese than in lean and than in elderly subjects, respectively. NMMA were $32 \%$ higher in obese than in lean subjects. ADMA differed by sex, being higher in men, namely by $1.75 \times$ in obese men and by $1.27 \times$ in elderly men. Postabsorptive ADMA $(r=0.71)$, SDMA $(r=0.46)$, and NMMA $(r=0.31)$ correlated (all $p<0.05)$ with rates of protein flux. All three MA correlated negatively with clamp glucose infusion rates and uptake $(p<0.001)$. ADMA and SDMA correlated negatively with net protein synthesis and clamp amino acid infusion rates
\end{abstract}

\footnotetext{
E. B. Marliss $(\bowtie) \cdot$ S. Chevalier $\cdot$ R. Gougeon $\cdot$ J. A. Morais M. Lamarche - O. A. J. Adegoke

McGill Nutrition and Food Science Centre,

MUHC-Royal Victoria Hospital,

687 Pine Avenue West Montreal, QC H3A 1A1, Canada

e-mail: marliss.errol@muhc.mcgill.ca

Tel.: +1-514-8431665

Fax: +1-514-8431706

G. $\mathrm{Wu}$

Faculty of Nutrition, Texas A\&M University,

College Station, TX 77843, USA
}

$(p<0.05)$. All MA also correlated with adiposity indices and fasting insulin and triglycerides $(p<0.05)$. Conclusions/ interpretation: Obesity, sex and ageing affect MA. Elevations of the three MA in obese, and of ADMA in elderly men, are related to increased protein turnover and to lesser insulin sensitivity of protein metabolism. These interrelationships might amplify insulin resistance and endothelial dysfunction.

Keywords Ageing - Insulin resistance $\cdot$ Methylarginines · Obesity $\cdot$ Protein turnover

Abbreviations ADMA: asymmetrical dimethylarginine . BCAA: branched-chain amino acids - DDAH:

dimethylarginine dimethylaminohydrolase $\cdot$ FFM: fat-free mass - MA: methylarginines - NOS: nitric oxide synthase NMMA: $N^{\mathrm{G}}$-monomethyl-L-arginine $\cdot \mathrm{Rd}$ : rate of disappearance - SDMA: symmetrical dimethylarginine

\section{Introduction}

Arginine may become methylated once incorporated into peptide linkages in proteins, and the resulting methylarginines (MA) are only demethylated after being released when the proteins are catabolised. Proteins containing MA are now known to have regulatory roles. Numerous fundamental cellular processes have been found to be subject to such regulation, including RNA processing, transcriptional regulation, signal transduction and DNA repair [1]. Such regulation has been suggested to be of similar importance to the ubiquitous phosphorylation processes that control the large families of kinases, phosphatases, and proteins containing phosphoprotein-interacting molecules [1].

One of the most studied effects of free MA released upon proteolysis is that of free MA on nitric oxide [2]. Physiological levels of nitric oxide produced by endothelial cells influence relaxation of vascular smooth muscle cells. L-Arginine is the substrate for nitric oxide synthases (NOS), and its plasma levels always exceed their $K_{\mathrm{m}}$ values [2]. 
However, the three MA, $N^{\mathrm{G}}$-monomethyl-L-arginine (NMMA), symmetrical dimethylarginine (SDMA) and asymmetrical dimethylarginine (ADMA), can act to decrease nitric oxide production [3]. Protein arginine $\mathrm{N}$-methyltransferases catalyse the conversion of protein-bound arginine to NMMA, which may be further methylated by protein arginine $N$-methyltransferases I and II to form ADMA and SDMA, respectively. Free NMMA and ADMA are inhibitors of NOS, with different potencies for different isoforms, and both are competitive inhibitors of arginine transport, whereas SDMA only inhibits the transport of arginine [2, 3], whose precise role at concentrations found in vivo remains to be defined [4].

In a number of clinical conditions associated with endothelial dysfunction, plasma dimethylarginine concentrations (especially ADMA) are elevated, and are now considered to be non-traditional cardiovascular disease risk factors. These conditions include hypertension and dyslipidaemia [2, 5], hyperhomocysteinaemia and renal failure [6,7], and diabetes [8], all conditions with insulin resistance $[5,7,8]$. Since insulin stimulates endothelial nitric oxide production, thereby increasing blood flow as one of its actions in enhancing glucose disposal, impaired nitric oxide synthesis is expected to contribute to insulin resistance. MA levels, when elevated, are relevant to their inhibitory properties in vitro and in vivo. For example, ADMA inhibits neural NOS with $K_{\mathrm{i}} 0.4 \mu \mathrm{mol} / 1, K_{\mathrm{ii}} 1.6 \mu \mathrm{mol} / 1$ and $\mathrm{IC}_{50}$ of $1.5 \mu \mathrm{mol} / 1$ [2]. However, the mechanism(s) that mediate elevations of plasma methylarginines are not completely understood. NMMA and ADMA are metabolised by dimethylarginine dimethylaminohydrolase (DDAH) to L-citrulline, and its activity regulates ADMA levels $[4,7,9]$. Control of circulating MA concentrations by the rates of protein turnover (especially of degradation) has not hitherto been studied in insulin-resistant humans.

Protein catabolism is increased in uncontrolled diabetes, and is corrected with restoration of normoglycaemia [10]. Furthermore, in states of lesser insulin resistance \pm insufficiency, alterations in protein turnover also occur [11-13]. Until recently, it has been considered that obesity does not regulate plasma methylarginine levels $[14,15]$, but this was in subjects with type 2 diabetes. We hypothesised: (1) that MA would be elevated in obese and elderly persons with reduced insulin sensitivity; (2) that protein turnover is a major regulator of plasma MA levels; and (3) that these two points are correlated. We have previously studied insulin sensitivity of glucose and protein metabolism in normal, obese and elderly subjects of both sexes $[11-13,16]$. Here, postabsorptive concentrations of the three MA were measured in 49 subjects, in whom glucose and protein sensitivity to insulin was studied. The MA results have been presented in part as Abstracts [17, 18].

\section{Subjects, materials and methods}

Non-diabetic, normotensive, otherwise healthy lean (ten men, eight women), obese (five men, ten women) and elderly (six men, ten women) subjects were screened by medical history, physical examination and laboratory investigation and a 75-g OGTT $[16,19]$. No medications or hormones were taken by subjects during their stay in the McGill University Health Centre/Royal Victoria Hospital's Clinical Investigation Unit. Subjects gave written informed consent. This protocol was approved by the Hospital Human Ethics Review Committee.

Lean subjects had BMI $<25 \mathrm{~kg} / \mathrm{m}^{2}$ and obese subjects $>30 \mathrm{~kg} / \mathrm{m}^{2}$. Women with regular menstrual cycles were studied during the follicular phase. Subjects received an individualised formula-based isoenergetic diet [16], based on resting metabolic rate by indirect calorimetry (Deltatrac; Sensor Medics, Yorba Linda, CA, USA) and on appropriate physical activity factors. Protein intake was $1.8 \mathrm{~g} / \mathrm{kg}$ fatfree mass (FFM) per day. Nitrogen balance studies were conducted during days 3 to $7[19,20]$. Body composition was assessed by bioelectrical impedance analysis (RJL101A Systems, Detroit, MI, USA) with equations validated for lean [21], obese [22] and elderly [23] subjects.

The hyperinsulinaemic clamp experiment was performed following the 7-day diet, as recently published [16], with glycaemia at $5.5 \mathrm{mmol} / 1$ and maintenance of individual subjects' postabsorptive plasma branched-chain amino acid (BCAA) concentrations. Glucose turnover was studied using a primed $(814 \mathrm{kBq})$, continuous infusion $(8.51 \mathrm{kBq} / \mathrm{min})$ of $\left[3-{ }^{3} \mathrm{H}\right]$ glucose, started $180 \mathrm{~min}$ prior to insulin and maintained throughout the clamp. At the same time, a primed $(0.5 \mathrm{mg} / \mathrm{kg})$, constant infusion of $\left[1-{ }^{13} \mathrm{C}\right]$ leucine was started at $0.008 \mathrm{mg} \mathrm{kg}^{-1} \mathrm{~min}^{-1}$, after an oral bolus of $0.1 \mathrm{mg} / \mathrm{kg}$ of $\mathrm{NaH}^{13} \mathrm{CO}_{3}$, to study leucine kinetics [24]. A primed infusion of human insulin (Humulin R; Eli Lilly Canada, Toronto, ON, Canada) was started at $0 \mathrm{~min}$ and continued at a rate of $40 \mathrm{mU} \mathrm{m}^{-2} \mathrm{~min}^{-1}$ for at least $210 \mathrm{~min}$. At $4 \mathrm{~min}, 20 \%(\mathrm{w} / \mathrm{v})$ potato starchderived glucose (Avebe, Foxhol, the Netherlands) in water with added $\left[3-{ }^{3} \mathrm{H}\right]$ glucose [25] was infused at variable rates. Baseline concentrations of plasma amino acids were maintained with 10\% TrophAmine (B. Braun Medical, Irvine, CA, USA) by adjusting infusion rates on the basis of plasma BCAA concentrations measured every $5 \mathrm{~min}$.

Blood samples were collected every $10 \mathrm{~min}$ for $40 \mathrm{~min}$ prior to the insulin infusion, then every $30 \mathrm{~min}$, and every $10 \mathrm{~min}$ during the last $40 \mathrm{~min}$. Indirect calorimetry was performed for $20 \mathrm{~min}$ prior to and during the last $30 \mathrm{~min}$ of the insulin infusion [26]. Glucose turnover was calculated as specified in $[25,27]$. Expired air samples were collected into a collection balloon, and transferred to 10-ml tubes (Vacutainer; Becton Dickinson Vacutainer Systems, Franklin Lakes, NJ, USA). Leucine kinetics were calculated according to the stochastic model [24], using plasma $\alpha$-ketoisocaproic acid as an index of the precursor pool enrichment (reciprocal model). In the postabsorptive state, the endogenous leucine rate of appearance determines protein catabolism and is equivalent to total flux. Protein flux is also equal to protein synthesis plus oxidation. Our studies demonstrated that background enrichment of expired ${ }^{13} \mathrm{CO}_{2}$ was diluted by $10.1 \pm 1.6 \%$ in lean [16] and elderly [13] and $7.0 \pm 1.7 \%$ in obese subjects [11]. Recovery factors for ${ }^{13} \mathrm{C}$ from the bicarbonate pool, 
obtained by separate experiments with $\left[{ }^{13} \mathrm{C}\right]$ bicarbonate infusions, were 0.671 in the postabsorptive state and 0.799 during the clamp period, and were used in all groups.

Fasting plasma ADMA, SDMA, and NMMA were measured by HPLC [5], and glucose was measured by the glucose oxidase method (GM7 Micro-Stat; Analox Instruments, Lunenberg, MA, USA). Assays for immunoreactive insulin and glucagon, and glucose-specific activity are described in $[10,20]$. Plasma total BCAA were measured by a rapid enzymatic, fluorometric assay [16] during the clamp. Individual plasma amino acids were determined by ion-exchange HPLC with post-column ninhydrin detection [28] using a Beckman HPLC System (Beckman Coulter, Fullerton, CA, USA). The $\left[{ }^{13} \mathrm{C}\right]$ enrichment of plasma $\alpha$-ketoisocaproic acid was analysed by GC-MS (GCMS 5988A; Hewlett-Packard, Palo Alto, CA, USA) [16]. Expired air was analysed for ${ }^{13} \mathrm{CO}_{2}$ enrichment by isotope ratio mass spectrometry (Micromass 903D; Vacuum Generators, Winsford, Cheshire, UK).

Results are presented as mean \pm SEM. Subject data were compared by a factorial ANOVA with the Bonferroni test as post hoc analysis. A two-factor ANOVA, with group and sex as the main factors, was used to assess their effects on plasma concentrations of MA and identify possible interactions. Pearson's coefficient was used for correlations. Stepwise multiple regression analysis was performed to identify which of the candidate variables that were measured most strongly predict the plasma levels of each of the MA. The analyses were performed with SPSS 11.0 for Windows (SPSS, Chicago, IL, USA). The level of significance was set at $p<0.05$.

\section{Results}

Table 1 presents the subject characteristics. The obese subjects were of intermediate age, and compared with the lean and elderly subjects, had typical features of obesity, e.g. greater weight, BMI, FFM, fat mass, percentage (\%) body fat, and waist and hip circumferences and ratio. The expected sex-related differences were also present, and were consistent among groups, except for differences in weight or waist circumference in obese subjects. Table 2 shows data by group, as only serum creatinine in lean and elderly subjects was higher in men (not shown). Minor elevations in mean plasma glucose were present in elderly vs lean subjects. Fasting insulin was higher only in the obese group. Two-hour post-glucose glycaemia was higher in obese and elderly subjects. Six subjects in each of these groups (two obese men, three elderly men) had impaired glucose tolerance $(>7.8 \mathrm{mmol} / \mathrm{l})$. Both the obese and elderly group had higher total cholesterol than the lean one, while the elderly group had higher LDL cholesterol and the obese group lower HDL cholesterol than the lean group.

Table 1 Subject characteristics

\begin{tabular}{|c|c|c|c|c|c|c|}
\hline & & Lean & Obese & Elderly & $\begin{array}{l}\text { Sex-related } \\
\text { difference } \\
\text { ( } p \text { value })\end{array}$ & $\begin{array}{l}\text { Group difference } \\
(p \text { value })\end{array}$ \\
\hline \multirow[t]{2}{*}{ Number } & Women & 10 & 10 & 10 & & \\
\hline & Men & 8 & 5 & 6 & & \\
\hline \multirow[t]{2}{*}{ Age (years) } & Women & $24.1 \pm 1.4$ & $41.7 \pm 3.8^{\mathrm{a}}$ & $69.1 \pm 1.5^{\mathrm{a}, \mathrm{b}}$ & - & $<0.001$ \\
\hline & Men & $26.5 \pm 1.1$ & $32.8 \pm 5.4$ & $69.2 \pm 1.6^{\mathrm{a}, \mathrm{b}}$ & & \\
\hline \multirow[t]{2}{*}{ Body weight (kg) } & Women & $54.7 \pm 1.7$ & $96.2 \pm 5.0^{\mathrm{a}}$ & $57.5 \pm 2.3^{\mathrm{b}}$ & $<0.001$ & $<0.001$ \\
\hline & Men & $69.1 \pm 1.9$ & $109.4 \pm 7.0^{\mathrm{a}}$ & $72.6 \pm 5.7^{\mathrm{b}}$ & & \\
\hline \multirow[t]{2}{*}{ Height (cm) } & Women & $161.9 \pm 2.3$ & $162.0 \pm 2.2$ & $157.6 \pm 1.5$ & $<0.001$ & 0.022 \\
\hline & Men & $178.6 \pm 1.9$ & $176.4 \pm 3.0$ & $170.6 \pm 3.2^{\mathrm{a}}$ & & \\
\hline \multirow[t]{2}{*}{ BMI $\left(\mathrm{kg} / \mathrm{m}^{2}\right)$} & Women & $20.8 \pm 0.3$ & $36.6 \pm 1.6^{\mathrm{a}}$ & $23.1 \pm 0.8^{\mathrm{a}, \mathrm{b}}$ & - & $<0.001$ \\
\hline & Men & $21.7 \pm 0.5$ & $35.2 \pm 2.2^{\mathrm{a}}$ & $24.7 \pm 1.1^{\mathrm{a}, \mathrm{b}}$ & & \\
\hline \multirow[t]{2}{*}{ Fat-free mass $(\mathrm{kg})$} & Women & $41.3 \pm 0.7$ & $50.6 \pm 1.7^{\mathrm{a}}$ & $35.9 \pm 0.9^{\mathrm{a}, \mathrm{b}}$ & $<0.001$ & $<0.001$ \\
\hline & Men & $59.4 \pm 1.2$ & $63.7 \pm 1.9^{\mathrm{a}}$ & $52.4 \pm 2.6^{\mathrm{a}, \mathrm{b}}$ & & \\
\hline \multirow[t]{2}{*}{ Body fat (\%) } & Women & $24.2 \pm 1.9$ & $46.8 \pm 1.5^{\mathrm{a}}$ & $37.2 \pm 1.5^{\mathrm{a}, \mathrm{b}}$ & $<0.001$ & $<0.001$ \\
\hline & Men & $13.8 \pm 1.4$ & $35.5 \pm 2.7^{\mathrm{a}}$ & $26.8 \pm 2.8^{\mathrm{a}, \mathrm{b}}$ & & \\
\hline \multirow[t]{2}{*}{ Waist circumference $(\mathrm{cm})$} & Women & $67.6 \pm 1.1$ & $107.8 \pm 3.8^{\mathrm{a}}$ & $78.6 \pm 2.4^{\mathrm{a}, \mathrm{b}}$ & $<0.001$ & $<0.001$ \\
\hline & Men & $78.8 \pm 1.5$ & $112.0 \pm 3.7^{\mathrm{a}}$ & $92.1 \pm 4.9^{\mathrm{a}, \mathrm{b}}$ & & \\
\hline \multirow[t]{2}{*}{ Hip circumference $(\mathrm{cm})$} & Women & $92.8 \pm 1.1$ & $122.3 \pm 3.6^{\mathrm{a}}$ & $96.1 \pm 1.7^{\mathrm{b}}$ & - & $<0.001$ \\
\hline & Men & $92.3 \pm 1.4$ & $115.0 \pm 4.2^{\mathrm{a}}$ & $97.8 \pm 3.0^{\mathrm{b}}$ & & \\
\hline \multirow[t]{2}{*}{ Waist-to-hip ratio } & Women & $0.73 \pm 0.01$ & $0.88 \pm 0.03^{\mathrm{a}}$ & $0.82 \pm 0.02^{\mathrm{a}}$ & $<0.001$ & $<0.001$ \\
\hline & Men & $0.85 \pm 0.01$ & $0.98 \pm 0.01^{\mathrm{a}}$ & $0.94 \pm 0.03^{\mathrm{a}}$ & & \\
\hline
\end{tabular}

Means \pm SEM. Results were analysed by two-factor ANOVA. No sex-by-group significant interactions were found for these variables. Differences between groups were assessed by one-way ANOVA within each sex category with Bonferroni as post hoc analysis ${ }^{\mathrm{a}} p<0.05$ vs lean

${ }^{\mathrm{b}} p<0.05$ vs obese 
Table 2 Subject postabsorptive metabolic data

Mean \pm SEM. Differences among groups were assessed by oneway ANOVA with Bonferroni as post hoc analysis ${ }_{p} p<0.05$ vs lean ${ }^{\mathrm{b}} p<0.05$ vs obese

\begin{tabular}{lcccc}
\hline & Lean & Obese & Elderly & $\begin{array}{l}\text { Group difference } \\
(p \text { value })\end{array}$ \\
\hline Number & 18 & 15 & 16 & \\
Plasma glucose $(\mathrm{mmol} / \mathrm{l})$ & $4.86 \pm 0.06$ & $4.98 \pm 0.07$ & $5.13 \pm 0.07^{\mathrm{a}}$ & 0.017 \\
Plasma insulin $(\mathrm{pmol} / \mathrm{l})$ & $63 \pm 3$ & $122 \pm 12^{\mathrm{a}}$ & $69 \pm 5^{\mathrm{b}}$ & $<0.001$ \\
OGTT 2-h glucose $(\mathrm{mmol} / \mathrm{l})$ & $5.19 \pm 0.37$ & $7.62 \pm 1.79^{\mathrm{a}}$ & $8.24 \pm 0.68^{\mathrm{a}}$ & $<0.001$ \\
Total cholesterol $(\mathrm{mmol} / \mathrm{l})$ & $3.89 \pm 0.20$ & $4.84 \pm 0.22^{\mathrm{a}}$ & $5.24 \pm 0.19^{\mathrm{a}}$ & $<0.001$ \\
LDL cholesterol $(\mathrm{mmol} / \mathrm{l})$ & $2.19 \pm 0.21$ & $2.86 \pm 0.24$ & $3.22 \pm 0.17^{\mathrm{a}}$ & 0.003 \\
HDL cholesterol $(\mathrm{mmol} / \mathrm{l})$ & $1.37 \pm 0.05$ & $1.12 \pm 0.06^{\mathrm{a}}$ & $1.30 \pm 0.08$ & 0.029 \\
Triglycerides $(\mathrm{mmol} / \mathrm{l})$ & $0.98 \pm 0.14$ & $2.15 \pm 0.37^{\mathrm{a}}$ & $1.60 \pm 0.22$ & 0.006 \\
Serum creatinine $(\mu \mathrm{mol} / \mathrm{l})$ & $70 \pm 3$ & $70 \pm 2$ & $72 \pm 3$ & - \\
\hline
\end{tabular}

The obese subjects had higher triglycerides than lean subjects.

In all groups glycaemia increased significantly to $5.5 \mathrm{mmol} / \mathrm{l}$ during the clamp (for presentation of clamp results, see $[11-13,16])$. The same rate of insulin infusion per $\mathrm{m}^{2}$ resulted in higher increments in obese and elderly than in lean subjects. Hyperinsulinaemia suppressed the rate of glucose production completely in lean and elderly, but not in obese subjects. Glucose uptake or rate of disappearance (Rd) during the clamp, given in $\mathrm{mg} / \mathrm{min}$ and adjusted for FFM, was greatest in lean subjects, with lowest rates in obese participants (lean $471 \pm 23 \mathrm{mg} / \mathrm{min}$, obese $295 \pm 27 \mathrm{mg} / \mathrm{min}$, elderly $397 \pm 26 \mathrm{mg} / \mathrm{min}$ ). Glucose infusion rates closely paralleled glucose $\mathrm{Rd}$ and were lower in elderly and obese participants.

For ADMA (Fig. 1), both group and sex-related effects, as well as a group by sex interaction were seen. Thus in the obese men, ADMA levels were higher than in both of the other groups, whereas in obese women, they were higher than in lean subjects. In elderly subjects, only men had higher ADMA concentrations vs lean men and elderly women. SDMA and NMMA did not show sex-related differences, but higher concentrations were present in obese than in lean and elderly participants, whereas the latter two did not differ. Plasma arginine did not differ (lean $70 \pm 4$, obese $71 \pm 4$, elderly $73 \pm 3 \mu \mathrm{mol} / \mathrm{l}$ ).

Table 3 presents the correlation coefficients of the three MA with other variables related to body composition, insulin and lipids. All indices that reflect adiposity and its distribution were significantly correlated with each of the three MA. FFM was positively correlated with ADMA and SDMA. Correlation coefficients for ADMA with FFM were 0.799 in obese and 0.705 in elderly participants, $p<0.002$. Insulin was positively correlated with all three MA, as was 2-h OGTT glucose. Triglycerides were positively correlated with the three MA, and HDL cholesterol was negatively correlated with ADMA and SDMA. All correlations had higher coefficients in the 19 men than in the women, most notably for ADMA, e.g. $r>0.830$ for BMI, waist and hip circumferences and body fat. Levels of the three MA were correlated with each other $(r>0.604$, $p<0.001$, not shown).

ADMA and SDMA correlated positively with postabsorptive leucine oxidation, protein breakdown and synthesis, and NMMA correlated with breakdown and synthesis (Table 4). ADMA and SDMA were negatively correlated with net protein balance. These correlations were strongest in the 15 obese subjects, with ADMA
Fig. 1 Plasma concentrations of ADMA, SDMA and NMMA in lean $(L$, closed bars $)$, obese $(O B$, shaded bars), and elderly ( $E$, open bars) subjects. Means \pm SEM. Data were analysed with a two-factor ANOVA (group and sex). For ADMA: group effect $p<0.001$; sex effect $p<0.001$, group-by-sex interaction $p<0.001$. Since no sex-related differences and no sex-by-group interactions were found in SDMA and NMMA, data of men and women were pooled. ${ }^{\mathrm{a}} p<0.05$ vs lean; ${ }^{\mathrm{b}} p<0.05$ vs women; ${ }^{\mathrm{c}} p<0.05$ vs obese, by one-way ANOVA with post hoc Bonferroni analysis

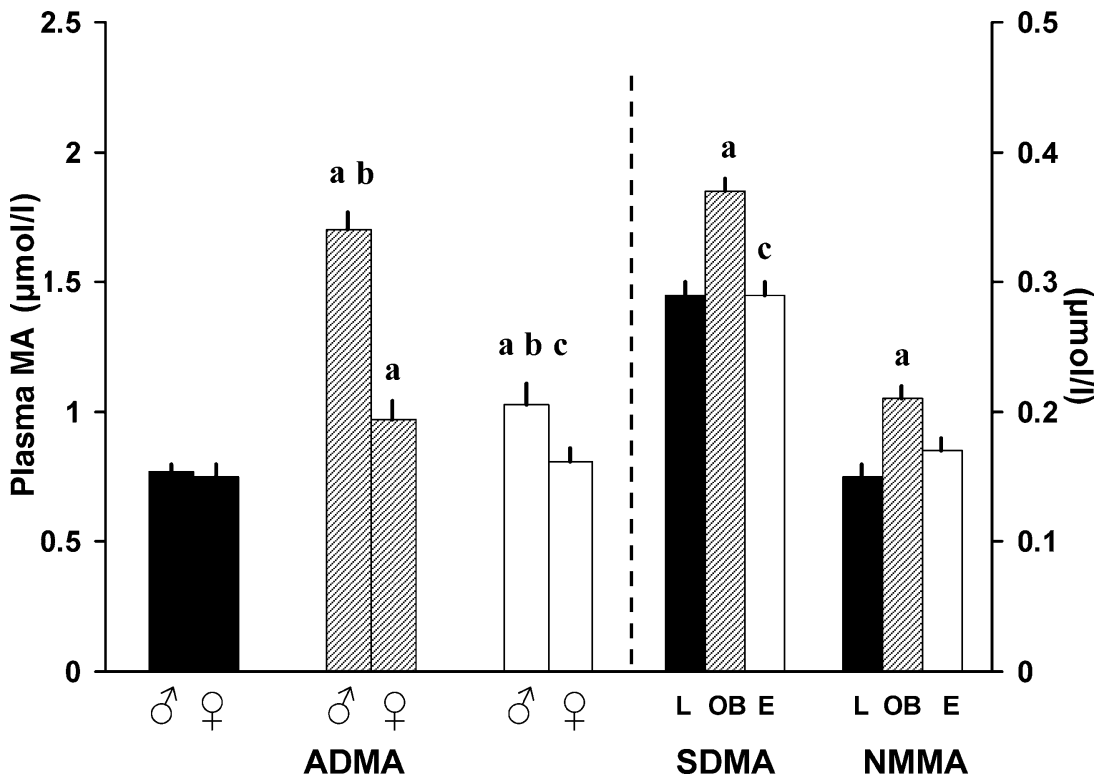


Table 3 Correlations between plasma methylarginines, body composition and plasma lipids

\begin{tabular}{lrrl}
\hline & ADMA & SDMA & NMMA \\
\hline Body weight (kg) & $0.684^{\mathrm{c}}$ & $0.544^{\mathrm{c}}$ & $0.416^{\mathrm{b}}$ \\
BMI $\left(\mathrm{kg} / \mathrm{m}^{2}\right)$ & $0.585^{\mathrm{c}}$ & $0.551^{\mathrm{c}}$ & $0.460^{\mathrm{c}}$ \\
Waist circumference (cm) & $0.658^{\mathrm{c}}$ & $0.581^{\mathrm{c}}$ & $0.473^{\mathrm{c}}$ \\
Hip circumference $(\mathrm{cm})$ & $0.484^{\mathrm{c}}$ & $0.507^{\mathrm{c}}$ & $0.399^{\mathrm{b}}$ \\
Waist-to-hip ratio & $0.597^{\mathrm{c}}$ & $0.434^{\mathrm{b}}$ & $0.376^{\mathrm{a}}$ \\
Body fat $(\mathrm{kg})$ & $0.536^{\mathrm{c}}$ & $0.510^{\mathrm{c}}$ & $0.431^{\mathrm{b}}$ \\
Body fat $(\%)$ & $0.315^{\mathrm{a}}$ & $0.377^{\mathrm{a}}$ & $0.339^{\mathrm{a}}$ \\
Fat-free mass (kg) & $0.566^{\mathrm{c}}$ & $0.336^{\mathrm{a}}$ & - \\
OGTT 2-h glucose (mmol/l) & $0.292^{\mathrm{a}}$ & $0.317^{\mathrm{a}}$ & $0.412^{\mathrm{b}}$ \\
Postabsorptive insulin (pmol/1) & $0.399^{\mathrm{b}}$ & $0.352^{\mathrm{a}}$ & $0.377^{\mathrm{a}}$ \\
Total cholesterol (mmol/l) & - & - & $0.309^{\mathrm{a}}$ \\
LDL cholesterol (mmol/1) & $0.303^{\mathrm{a}}$ & - & - \\
HDL cholesterol (mmol/l) & $-0.447^{\mathrm{b}}$ & $-0.327^{\mathrm{a}}$ & - \\
Triglycerides (mmol/l) & $0.312^{\mathrm{a}}$ & $0.313^{\mathrm{a}}$ & $0.420^{\mathrm{b}}$ \\
\hline Pearson's correlation coefficients $(n-49) . \mathrm{C}^{\mathrm{b}}$ & &
\end{tabular}

Pearson's correlation coefficients $(n=49)$. Correlations were assessed between the different variables and plasma methylarginines in $\mu \mathrm{mol} / 1$

${ }_{p}<0.05$

${ }^{\mathrm{b}} p<0.005$

${ }^{\mathrm{c}} p<0.001$

$r=0.806$ to 0.875 for oxidation, breakdown and synthesis, and -0.875 for net protein balance. Since protein kinetics and plasma MA were related to FFM, partial correlation analysis was performed to account for this effect. Significant correlations were still present between protein kinetics and MA (Table 4).

Indices of insulin resistance of glucose metabolism, clamp glucose infusion rates (not shown) and glucose uptake or Rd (Fig. 2) were negatively correlated with all three MA. Only when the three groups were pooled to obtain a data set with a range of insulin sensitivity, were these correlations found. Within each subgroup, only ADMA correlated significantly with glucose Rd in elderly subjects $(r=-0.59, p=0.017)$. ADMA and SDMA were negatively correlated with amino acid infusion rates during

Table 4 Correlations between postabsorptive protein kinetics and plasma methylarginines

\begin{tabular}{llll}
\hline & ADMA & SDMA & NMMA \\
\hline Oxidation & $0.629^{\mathrm{a}}$ & $0.444^{\mathrm{a}}$ & - \\
& $\left(0.332^{\mathrm{b}}\right)$ & $\left(0.361^{\mathrm{b}}\right)$ & - \\
Catabolism & $0.705^{\mathrm{a}}$ & $0.463^{\mathrm{a}}$ & $0.305^{\mathrm{b}}$ \\
& $\left(0.593^{\mathrm{a}}\right)$ & $\left(0.440^{\mathrm{a}}\right)$ & $\left(0.332^{\mathrm{b}}\right)$ \\
Synthesis & $0.710^{\mathrm{a}}$ & $0.454^{\mathrm{a}}$ & $0.306^{\mathrm{b}}$ \\
& $\left(0.563^{\mathrm{a}}\right)$ & $\left(0.373^{\mathrm{b}}\right)$ & $\left(0.297^{\mathrm{b}}\right)$ \\
Net balance & $-0.629^{\mathrm{a}}$ & $-0.444^{\mathrm{a}}$ & - \\
& $\left(-0.332^{\mathrm{b}}\right)$ & $\left(-0.361^{\mathrm{b}}\right)$ & - \\
\hline
\end{tabular}

Significant Pearson's correlation coefficients $(n=49)$. Correlations were assessed between protein kinetics, in $\mu \mathrm{mol}$ of leucine $/ \mathrm{min}$ and plasma methylarginines in $\mu \mathrm{mol} / \mathrm{l}$. Values in parentheses: partial correlations controlled for fat-free mass ${ }^{\mathrm{a}} p<0.005$

${ }_{p} p<0.05$ the clamp (Fig. 3). The glucose and amino acid infusion rates were correlated with each other $(r=0.531, p<0.001)$, indicating an association of the two with respect to sensitivity to insulin.

As many of the variables that correlated with the three MA were inter-correlated (e.g. adiposity with plasma lipids and insulin resistance), stepwise multiple regression anal-
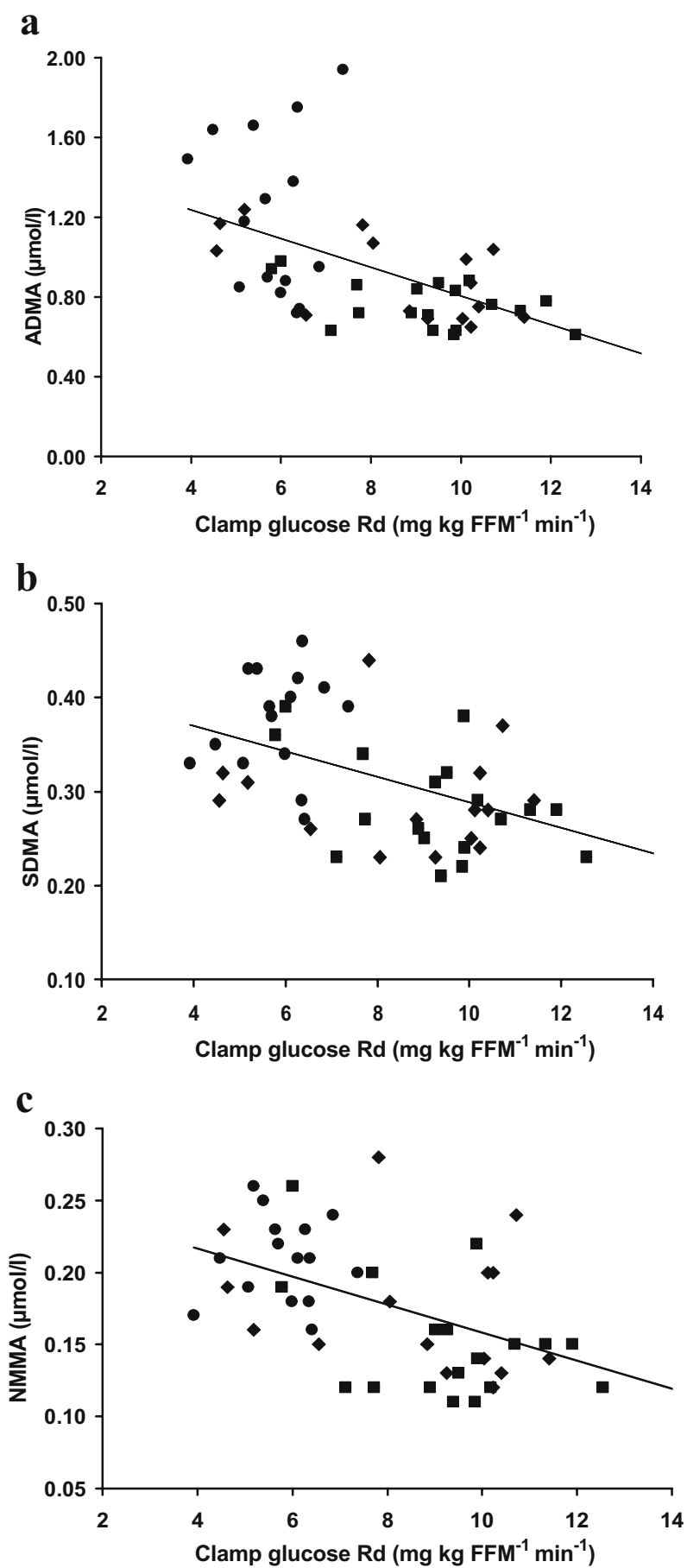

Fig. 2 Correlations between plasma concentrations of a ADMA $(r=-0.548, p<0.001)$, b SDMA $(r=-0.497, p=0.003)$, and c NMMA $(r=-0.519, p=0.001)$ and glucose sensitivity to insulin. Pearson's correlation coefficients. Squares: lean; circles: obese; diamonds: elderly. $R d$ Rate of disappearance, FFM Fat-free mass 

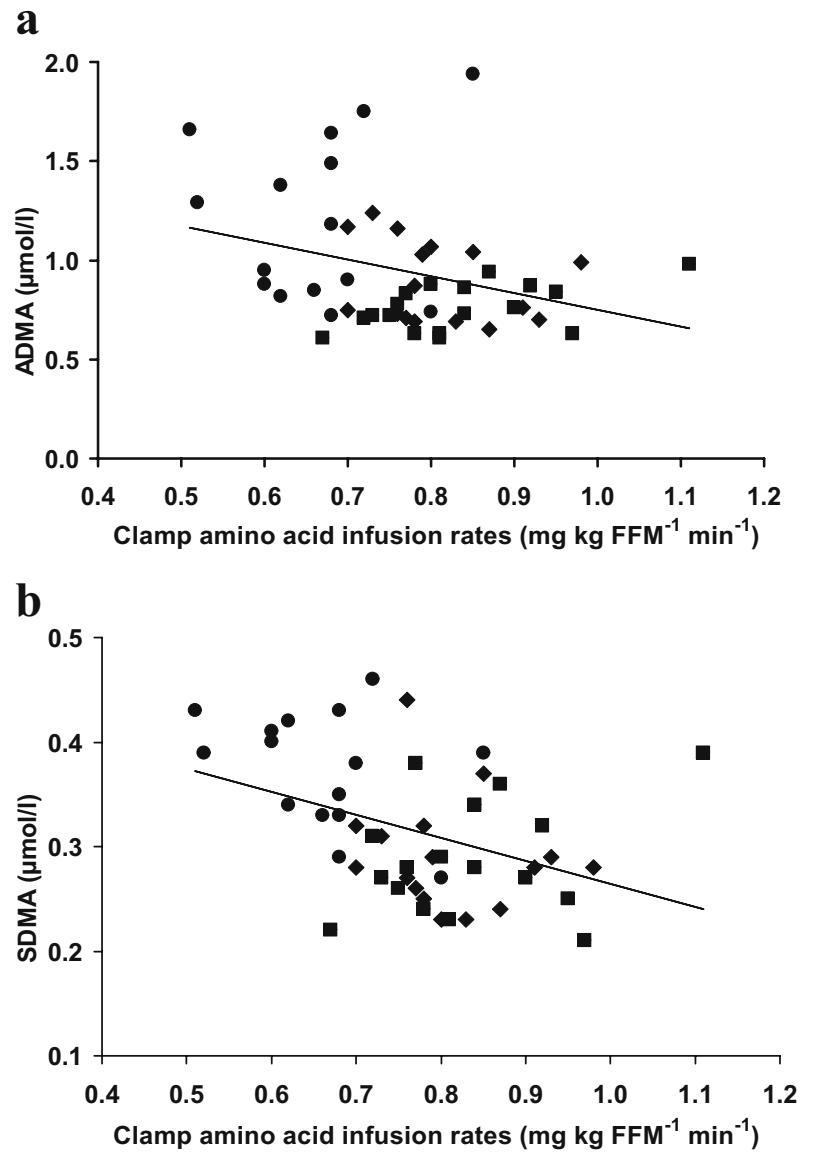

Fig. 3 Correlations between plasma concentrations of a ADMA $(r=-0.615, p=0.028)$ and $\mathbf{b}$ SDMA $(r=-0.396, p=0.005)$ and protein sensitivity to insulin, indicated by clamp amino acid infusion rates. Pearson's correlation coefficients. Infusion rates were not significantly correlated with NMMA. Squares: lean; circles: obese; diamonds: elderly. FFM Fat-free mass

ysis was performed to determine which variables were the strongest predictors of each MA (Table 5). Since rates of postabsorptive protein synthesis and catabolism were so

Table 5 Stepwise multiple regression analysis of variables predicting plasma concentrations of methylarginines

\begin{tabular}{llll}
\hline & ADMA & SDMA & NMMA \\
\hline Postabsorptive & 0.783 & & \\
protein flux & $(p<0.001)$ & \\
( $\mu$ mol/min) & & & \\
Clamp glucose & -0.442 & & \\
Rd (mg/min) & $(p=0.003)$ & $(p=0.046)$ \\
LDL cholesterol & 0.327 & & \\
(mmol/1) & $(p=0.035)$ & 0.428 \\
Waist & & 0.581 & $(p<0.004)$ \\
circumference $(\mathrm{cm})$ & & $(p<0.001)$ & $(p<04$ \\
\hline
\end{tabular}

Partial correlation coefficients are presented. They reflect the correlation between the listed variables and each of the MA after removing the effects of the linear relationships between variables. Variables excluded from the model include all other variables listed in Tables 3 and 4, as well as age, sex and amino acid infusion rates $R d$ Rate of disappearance closely related to each other $(r=0.97, p<0.001)$, they accounted for the variance in plasma ADMA to the same extent. Therefore, endogenous protein flux was the strongest predictor of plasma ADMA, followed by glucose Rd during the clamp (index of insulin sensitivity of glucose) and by LDL cholesterol. Collectively, these variables accounted for $64 \%$ of the ADMA variance. Waist circumference (an index of abdominal adiposity) was the only variable significantly correlated with plasma SDMA concentrations, when relationships with other variables were removed, accounting for $34 \%$ of the variance. Together, waist circumference and glucose Rd explained 30\% of the variance in NMMA.

\section{Discussion}

Insulin resistance of glucose metabolism characterises several clinical states in which plasma MA levels are increased $[5-8,14,29]$, and we have demonstrated that insulin resistance of protein metabolism occurs in some of those states [11-13]. We therefore postulated that one manifestation of such resistance, via altered protein turnover, might be the increased release of MA into the circulation. Synthesis and breakdown of methylated proteins have previously been shown to be coupled to protein synthesis and catabolism only in the mouse [30]. The rate-limiting steps that could affect plasma levels of MA are: (1) incorporation of arginine into the polypeptide; (2) methylation of arginines in peptide linkages (by types I and II protein arginine $\mathrm{N}$-methyltransferases); (3) protein degradation; (4) the intracellular catabolism of ADMA and NMMA by DDAHs [3, 4, 9] and their transport out of the cell and uptake by other tissues [4]; and finally (5) renal excretion $[6,31]$. MA accumulate in plasma in renal insufficiency $[6,32,33]$, which is often a protein-catabolic state. Recent studies suggest that DDAH activity plays a regulatory role in NMMA and ADMA catabolism in animal tissues $[4,9,34,35]$. However, the relative importance of each of the possible mechanisms for the elevated plasma levels in humans, especially those with insulin resistance, has not yet been defined.

An important finding of the present study is that rates of whole-body protein turnover are associated with plasma levels of MA (Table 4), especially ADMA. We were unable to find published data that assessed MA and protein kinetics in the same subjects. Elevated plasma levels of MA have been predicted to be associated with states of increased protein breakdown due to a variety of 'stress' states [9], but without supportive human data other than increased renal ADMA excretion in muscular dystrophy [36]. The rates of release of NMMA, ADMA and SDMA from methylated proteins depend on the rates of protein catabolism. However, if protein synthesis rates are altered, the number of MA synthesised will be affected, and thereby influence the number available to be released by catabolism. Rates of protein synthesis and catabolism are controlled by multiple factors. Certain of these factors may affect both rates, though not always in the same direction or 
to the same extent, depending on the nutritional (fasting vs postprandial) and physiological state. In our subjects with a range of insulin sensitivities, the positive correlations of MA with both synthesis and catabolism of whole-body protein (Table 4) are consistent with the fact that both rates are strongly correlated in the net catabolic state after an overnight fast. This supports the conclusion that protein turnover plays an important role in regulating plasma levels of MA in humans. For ADMA, this effect was independent of adiposity.

We found a significant relationship between results from the gold-standard measurement of insulin resistance of glucose metabolism (the hyperinsulinaemic-euglycaemic clamp) and plasma ADMA, SDMA and NMMA (Fig. 2). Insulin sensitivity of glucose and of protein turnover were significantly correlated, indicating that persons with resistance of glucose metabolism have resistance of protein metabolism concurrently. Since the hyperinsulinaemic clamp quantified the insulin sensitivity of whole-body protein turnover, we assessed the relationship of its responses to postabsorptive plasma MA concentrations. Because the clamp amino acid infusion rates were lower with insulin resistance, these rates are viewed as a simple and plausible index of assessing the sensitivity of protein metabolism to insulin [11]. They were negatively correlated to ADMA and SDMA (Fig. 3). The significant correlations across the ranges of insulin sensitivity in the whole group could be attributable to a multiple-group effect. However, the basic design of our study was to test the primary hypothesis, and with the exception of obese subjects, the narrow ranges of insulin sensitivity within each of the subgroups, as well as the numbers of subjects, precluded demonstration of such intra-group correlations.

The anthropometric variables that are associated with obesity were all strongly correlated with plasma MA, and waist circumference was found to be an independent variable predicting plasma levels of SDMA and NMMA. Our subjects did not have other conditions associated with increased MA, e.g. hypertension, hyperlipidaemia, renal or hepatic disease, or diabetes. Further, we demonstrated elevations of all three MA in obesity, as reported in the Zucker rat [37]. Most prior human studies have reported only on ADMA, some also on SDMA, but rarely on all three. A recent study of morbidly obese women (BMI $49 \pm 1 \mathrm{~kg} / \mathrm{m}^{2}$ ) reported plasma ADMA concentrations similar to those of our obese women. These concentrations decreased after bariatric surgery to reduce BMI to $34 \pm 1 \mathrm{~kg} / \mathrm{m}^{2}$. However, both ADMA and SDMA were still elevated compared with those of lean women [38]. Thus, obesity itself is associated with increased plasma MA. This applies in both sexes and across a wide age range.

We are unaware of published data on sex-related differences in plasma ADMA, as the literature cited has pooled results of both sexes or reported only on one sex. The markedly greater elevation in obese men than women raises the possibility of a difference in the activity of protein arginine $\mathrm{N}$-methyltransferase I. The strongest correlates of ADMA were rates of protein turnover, which are dependent upon FFM, and the fact that the obese males had the highest FFM is of interest in this regard. The elderly men showed elevations compared with lean subjects, albeit smaller than those of obese men. Without controlling for sex, an increase with age has been reported in humans [39]. The elevated plasma levels of ADMA in subjects with a mean age of 70 years and without hypertension were even higher with hypertension [40]. A large study reported that plasma levels of ADMA were higher in elderly men than is usually reported in young, lean men, and were further increased in those who were obese [41]. We found no sex-related difference in SDMA or NMMA in any of our groups (Fig. 1), nor any effect of age (consistent with [39]) for SDMA and NMMA. It should be borne in mind that the number of subjects in our study precludes these sex-related and age differences being definitive findings, and requires confirmation in larger cohorts. Based on our results, it is possible that changes in body composition accompanying the ageing process, especially the increase in the proportion of adipose tissue [13], are responsible for some of the findings reported above.

Plasma arginine levels are unlikely to be rate-limiting for protein synthesis in our groups of subjects, as they did not differ, and oral arginine supplementation, despite increasing plasma arginine levels, did not increase plasma ADMA or SDMA [42]. However, a significant contributor to the MA differences found by us is likely to be DDAH activity $[4,9,34,43,44]$. From a different perspective, our results support the previous suggestion [9] that plasma MA might be a useful index of body protein catabolism, though more data across a wide range of increased protein turnover would be required for confirmation. SDMA is likely to be the best candidate for this, as its main pathway of disposal is via renal excretion. Interestingly, urinary excretion of $\mathrm{N}^{\tau}$. methylhistidine has been used as an index of muscle protein catabolism, as the methylation of protein-bound histidine residues is relatively specific to muscle protein and is not degraded upon proteolysis [19, 45, 46]. However all meat must be removed from the diet, as it contains methylhistidine. To our knowledge, this has not been addressed in studies of circulating MA in humans, where a similar effect of dietary protein might occur. The present study rigorously controlled protein source and intake. The only study that addressed diet composition did so in hypercholesterolaemic subjects of both sexes, with an age range of 35 to 62 years and BMI of 18 to $30 \mathrm{~kg} / \mathrm{m}^{2}$, and did not control for sex, age or BMI [47]. An unexplained negative association between reported percentage (\%) carbohydrate intake and ADMA was found, but insulin and insulin resistance data were not obtained.

Our results are pertinent to the observations of a relationship between insulin resistance of glucose metabolism and ADMA levels in subjects with and without type 2 diabetes $[5,8,48]$, whose BMI range was 21 to $37 \mathrm{~kg} / \mathrm{m}^{2}$ and age range 25 to 72 years. We predict that the insulinresistant subjects of these previous studies would have had insulin resistance of protein metabolism, and that treatment with rosiglitazone [5] or metformin [48] would have decreased that resistance, contributing to the decreased 
plasma ADMA with treatment. We have shown that a hyperglycaemia-associated increase in protein turnover could be normalised during euglycaemia with diet, metformin and sulfonylurea treatment [10]. In this regard, it is noteworthy that decreased aortic DDAH activity correlates positively with elevated plasma ADMA in streptozotocininduced diabetes in rats [49]. Hyperglycaemia is also associated with increased protein catabolism in such animals [45], which would also be expected to contribute to elevated levels of plasma ADMA. Studies of human diabetes that relate protein turnover to plasma MA levels are presently lacking.

In conclusion, we have provided evidence that increased protein turnover plays a role in the elevated plasma MA in insulin-resistant subjects, adding to the data regarding the regulation of methylarginine metabolism in humans. Our evidence is based on correlations that do not permit inferences as to cause versus effect. Irrespective of whether insulin resistance contributes to increased protein turnover and thereby results in increased plasma MA concentrations, or whether the increased concentrations cause the insulin resistance, or both, the end result would be to amplify the abnormality and worsen the metabolic syndrome. Our data and their interpretation fit well with those conditions in which we and others have shown increases in whole-body protein degradation, especially in poorly controlled diabetes, and that these improve with better metabolic control. A potential therapeutic target for normalising MA as cardiovascular risk factors is therefore the normalisation of protein turnover. We suggest that all subsequent studies of ADMA in humans should be controlled for sex and age in their analyses. Finally, with the emerging evidence that arginine methylation regulates protein function [1], it is conceivable that the increase in protein turnover shown by us in states of insulin resistance could lead to many regulatory abnormalities via the pathways affected.

Acknowledgements The authors gratefully acknowledge the nursing assistance of M. Shingler, technical expertise from M. Giroux, G. Sabourin, C. Nardolillo, and P. Meillon, and the secretarial expertise of J. Plescia and K. French. This study was supported by research grants from the Canadian Institutes of Health Research to E. B. Marliss (MOP-42500) and R. Gougeon (MOP15487), and from the Canadian Diabetes Association to J. A. Morais. It was also supported by salary awards to R. Gougeon from the McGill University Health Centre Research Institute and to J. A. Morais from Fonds de la recherche en santé du Québec (Quebec Health Research Fund), and by the Neil M. Miller fellowship to S. Chevalier from the Canadian Diabetes Association.

\section{References}

1. Bedford MT, Richard S (2005) Arginine methylation an emerging regulator of protein function. Mol Cell 18:263-272

2. Tsikas D, Boger RH, Sandmann J, Bode-Boger SM, Frolich JC (2000) Endogenous nitric oxide synthase inhibitors are responsible for the L-arginine paradox. FEBS Lett 478:1-3

3. Flynn NE, Meininger CJ, Haynes TE, Wu G (2002) The metabolic basis of arginine nutrition and pharmacotherapy. Biomed Pharmacother 56:427-438
4. Vallance P, Leiper J (2004) Cardiovascular biology of the asymmetric dimethylarginine:dimethylarginine dimethylaminohydrolase pathway. Arterioscler Thromb Vasc Biol 24:10231030

5. Stuhlinger MC, Abbasi F, Chu JW et al (2002) Relationship between insulin resistance and an endogenous nitric oxide synthase inhibitor. JAMA 287:1420-1426

6. Wahbi N, Dalton RN, Turner C, Denton M, Abbs I, Swaminathan R (2001) Dimethylarginines in chronic renal failure. J Clin Pathol $54: 470-473$

7. Nash DT (2002) Insulin resistance, ADMA levels, and cardiovascular disease. JAMA 287:1451-1452

8. Abbasi F, Asagami T, Cooke JP et al (2001) Plasma concentrations of asymmetric dimethylarginine are increased in patients with type 2 diabetes mellitus. Am J Cardiol 88:12011203

9. Tran CT, Leiper JM, Vallance P (2003) The DDAH/ADMA/ NOS pathway. Atheroscler [Suppl 4]:33-40

10. Gougeon R, Styhler K, Morais JA, Jones PJ, Marliss EB (2000) Effects of oral hypoglycemic agents and diet on protein metabolism in type 2 diabetes. Diabetes Care 23:1-8

11. Chevalier S, Marliss EB, Morais JA, Gougeon R (2005) Insulin resistance of whole-body protein metabolism in obese women. Am J Clin Nutr 82:355-365

12. Chevalier S, Marliss EB, Morais JA, Lamarche M, Gougeon R (2005) The influence of sex on the protein anabolic response to insulin. Metabolism 54:1529-1535

13. Chevalier S, Gougeon, R., Choong, N., Lamarche, M., Morais J.A. Influence of adiposity in the blunted whole-body protein anabolic response to insulin with aging. J Gerontol A Biol Sci Med Sci (in press)

14. Chan NN, Chan JC (2002) Asymmetric dimethylarginine (ADMA): a potential link between endothelial dysfunction and cardiovascular diseases in insulin resistance syndrome? Diabetologia 45:1609-1616

15. Hogikyan RV, Galecki AT, Pitt B, Halter JB, Greene DA, Supiano MA (1998) Specific impairment of endotheliumdependent vasodilation in subjects with type 2 diabetes independent of obesity. J Clin Endocrinol Metab 83:1946-1952

16. Chevalier S, Gougeon R, Kreisman SH, Cassis C, Morais JA (2004) The hyperinsulinemic amino acid clamp increases whole-body protein synthesis in young subjects. Metabolism 53:388-396

17. Chevalier S, Wu G, Gougeon R, Morais JA, Marliss EB (2004) Insulin resistance of glucose and protein is associated with increased plasma concentrations of methylarginines. Can J Diabetes 2:259

18. Marliss EB, Chevalier S, Gougeon R, Morais JA, Wu G (2004) Elevated plasma levels of methylarginines are associated with insulin resistance in obese and aged humans. Diabetes 53: 1290-P

19. Morais JA, Gougeon R, Pencharz PB, Jones PJ, Ross R, Marliss EB (1997) Whole-body protein turnover in the healthy elderly. Am J Clin Nutr 66:880-889

20. Gougeon R, Pencharz PB, Sigal RJ (1997) Effect of glycemic control on the kinetics of whole-body protein metabolism in obese subjects with non-insulin-dependent diabetes mellitus during iso- and hypoenergetic feeding. Am J Clin Nutr 65:861870

21. Goran MI, Khaled MA (1995) Cross-validation of fat-free mass estimated from body density against bioelectrical resistance: effects of obesity and gender. Obes Res 3:531-539

22. Kushner RF, Schoeller DA, Fjeld CR, Danford L (1992) Is the impedance index (ht2/R) significant in predicting total body water? Am J Clin Nutr 56:835-839

23. Roubenoff R, Baumgartner RN, Harris TB et al (1997) Application of bioelectrical impedance analysis to elderly populations. J Gerontol A Biol Sci Med Sci 52:M129-136

24. Matthews DE, Motil KJ, Rohrbaugh DK, Burke JF, Young VR, Bier DM (1980) Measurement of leucine metabolism in man from a primed, continuous infusion of $\mathrm{L}-\left[1-{ }^{3} \mathrm{C}\right]$ leucine. Am J Physiol 238:E473-479 
25. Finegood DT, Bergman RN, Vranic M (1987) Estimation of endogenous glucose production during hyperinsulinemic-euglycemic glucose clamps. Comparison of unlabeled and labeled exogenous glucose infusates. Diabetes 36:914-924

26. Bogardus C, Ravussin E, Robbins DC, Wolfe RR, Horton ES, Sims EA (1984) Effects of physical training and diet therapy on carbohydrate metabolism in patients with glucose intolerance and non-insulin-dependent diabetes mellitus. Diabetes 33:311318

27. Saad MF, Anderson RL, Laws A et al (1994) A comparison between the minimal model and the glucose clamp in the assessment of insulin sensitivity across the spectrum of glucose tolerance. Insulin Resistance Atherosclerosis Study. Diabetes 43:1114-1121

28. Slocum RH, Cummings JG (1991) Amino acid analysis of physiological samples. In: Hommes FA (ed) Techniques in diagnostic human biochemical genetics - a laboratory manual. Wiley-Liss, NY, pp 89-126

29. Leiper J, Vallance P (1999) Biological significance of endogenous methylarginines that inhibit nitric oxide synthases. Cardiovasc Res 43:542-548

30. Miyake M, Kakimoto Y (1976) Synthesis and degradation of methylated proteins of mouse organs: correlation with protein synthesis and degradation. Metabolism 25:885-896

31. Kakimoto Y, Akazawa S (1970) Isolation and identification of $\mathrm{N}$-G, $N$-G- and $N$-G, $N$ '-G-dimethyl-arginine, $N$-epsilon-mono-, di-, and trimethyllysine, and glucosylgalactosyl- and galactosyl-delta-hydroxylysine from human urine. J Biol Chem 245: 5751-5758

32. Zoccali C, Bode-Boger S, Mallamaci F et al (2001) Plasma concentration of asymmetrical dimethylarginine and mortality in patients with end-stage renal disease: a prospective study. Lancet 358:2113-2117

33. Vallance P, Leone A, Calver A, Collier J, Moncada S (1992) Accumulation of an endogenous inhibitor of nitric oxide synthesis in chronic renal failure. Lancet 339:572-575

34. Smith CL, Birdsey GM, Anthony S, Arrigoni FI, Leiper JM, Vallance P (2003) Dimethylarginine dimethylaminohydrolase activity modulates ADMA levels, VEGF expression, and cell phenotype. Biochem Biophys Res Commun 308:984-989

35. Fard A, Tuck CH, Donis JA et al (2000) Acute elevations of plasma asymmetric dimethylarginine and impaired endothelial function in response to a high-fat meal in patients with type 2 diabetes. Arterioscler Thromb Vasc Biol 20:2039-2044

36. Inoue R, Miyake M, Kanazawa A, Sato M, Kakimoto Y (1979) Decrease of 3-methylhistidine and increase of $N G$, NGdimethylarginine in the urine of patients with muscular dystrophy. Metabolism 28:801-804
37. Fu WJ, Haynes TE, Kohli R et al (2005) Dietary L-arginine supplementation reduces fat mass in Zucker diabetic fatty rats. J Nutr 135:714-721

38. Krzyzanowska K, Mittermayer F, Kopp HP, Wolzt M, Schernthaner G (2004) Weight loss reduces circulating asymmetrical dimethylarginine concentrations in morbidly obese women. J Clin Endocrinol Metab 89:6277-6281

39. Miyazaki H, Matsuoka H, Cooke JP et al (1999) Endogenous nitric oxide synthase inhibitor: a novel marker of atherosclerosis. Circulation 99:1141-1146

40. Kielstein JT, Bode-Boger SM, Frolich JC, Ritz E, Haller H, Fliser D (2003) Asymmetric dimethylarginine, blood pressure, and renal perfusion in elderly subjects. Circulation 107:18911895

41. Eid HM, Arnesen H, Hjerkinn EM, Lyberg T, Seljeflot I (2004) Relationship between obesity, smoking, and the endogenous nitric oxide synthase inhibitor, asymmetric dimethylarginine. Metabolism 53:1574-1579

42. Chan JR, Boger RH, Bode-Boger SM et al (2000) Asymmetric dimethylarginine increases mononuclear cell adhesiveness in hypercholesterolemic humans. Arterioscler Thromb Vasc Biol 20:1040-1046

43. Ito A, Tsao PS, Adimoolam S, Kimoto M, Ogawa T, Cooke JP (1999) Novel mechanism for endothelial dysfunction: dysregulation of dimethylarginine dimethylaminohydrolase. Circulation 99:3092-3095

44. Stuhlinger MC, Tsao PS, Her JH, Kimoto M, Balint RF, Cooke JP (2001) Homocysteine impairs the nitric oxide synthase pathway: role of asymmetric dimethylarginine. Circulation 104:2569-2575

45. Nakhooda AF, Wei CN, Marliss EB (1980) Muscle protein catabolism in diabetes: 3-methylhistidine excretion in the spontaneously diabetic "BB" rat. Metabolism 29:1272-1277

46. Marliss EB, Wei CN, Dietrich LL (1979) The short-term effects of protein intake on 3-methylhistidine excretion. Am J Clin Nutr 32:1617-1621

47. Paiva H, Lehtimaki T, Laakso J et al (2004) Dietary composition as a determinant of plasma asymmetric dimethylarginine in subjects with mild hypercholesterolemia. Metabolism 53:1072-1075

48. Asagami T, Abbasi F, Stuelinger M et al (2002) Metformin treatment lowers asymmetric dimethylarginine concentrations in patients with type 2 diabetes. Metabolism 51:843-846

49. Lin KY, Ito A, Asagami T et al (2002) Impaired nitric oxide synthase pathway in diabetes mellitus: role of asymmetric dimethylarginine and dimethylarginine dimethylaminohydrolase. Circulation 106:987-992 